\title{
Seccurity
}

$351,746.5: 334.73(497.11)$

Scientific article

\section{CORPORATE SECURITY IN PRIVATE SECTOR OF THE REPUBLIC OF SERBIA}

\author{
Ljubo Pejanović, PhD \\ Faculty of Legal and Business Studies, Novi Sad, Serbia \\ E-mail: pejanovicljubo@gmail.com \\ Marija Mitić, PhD candidate \\ Faculty of Legal and Business Studies, Novi Sad, Serbia
}

\begin{abstract}
This paper is aimed to corporate security, their connections, similarities and differences in relation to the corporation are engaged the security in the Republic of Serbia. Corporate security problem is presented in numerous ways, names, explanations and interpretations, which makes it necessary concrete explanation, definition and articulation in a better and more specific mode of action of these institutions in the private security sector. To solve the problem scientifically explain the corporate and corporate security, it is necessary to do empirical research within the framework of existing institutions and engaged corporate security within corporations. In order to reach the goal of this article shall apply the method of analysis, which will be made unbundling more complex concepts into simple elements, to dissect the elements and their interrelations and connections. While the method of synthesis will be made of its research and explanations and connecting ideas in a simple thought complex and connecting parts and their relationships in a continent such as corporation. After the research questions, will be adequate answers, definitions and reasoning given problem.
\end{abstract}

Key words: Corporate, corporate, agreed, conventional, security. 


\section{Secuurity}

\section{Introduction}

This paper deals with the problem of corporate security as the subject of conventional security in the private sector, whether it is in corporations, companies, agencies, companies and the citizens. Thereby, this phenomenon In doing so, this phenomenon implies stable, responsive, established and traditional-social approach to protecting corporations from all forms of destructive threats and risks. This activity involves the realization of the security property, capital and people who exercise of all forms of destructive threats in a certain area that is space Corporations itself. In this regard, the Corporation, is a special form of organization of a number of people of the same profession and the capital, which is in accordance with the laws of the state where the organize certain activities. In this sense, the corporation represents the corporate system of joint activities and capital. Accordingly, in the conceptual definition of the term corporation refers to corporate activity, in which the corporate security contained as an internal and agreed to protect corporate entity. This type of organization, approved by the state in order to operate and conduct business in which it acquires capital which is the goal of this association. The aim of the research in this article is focused precisely on internal protection of the capital and all values in the Corporation. One of the key problems in the study of needs, professional activities and the role of the private corporate security activities in the Republic of Serbia, which refers to the prevention of destructive activities, it is inadequate laws and subordinate legislation. When it comes to the law on private security is inadequate in relation to the Corporation's foreign capital, because it does not involve the same corporate security. While, in the form of sub-legal norms of the Rules is not yet saw the light of day, and on the application we can not talk yet. Therefore, internal norms in corporations can be adjusted according to the laws that have not been completed in accordance with these Institutions. In this sense, the problem in this area and in the social sector where jobs are organized independent safety and protection of people and property that does not protect its country. Therefore, the law on private security is not only corporate, but also regulate private security and their activities in foreign corporations. While foreign corporations internal corporate security regulate its internal bylaws. In this regard the law on private security was partially regulates the issue of private security and its agreedconventional function in the security of people and property.

When it comes to the society of the Republic of Serbia and its legality related to this activity, in which appears between the other and the problem of applying the law of the Corporation, which was organized and established in another country, a part thereof or daughter company is in the territory of the Republic Serbia. The problem in the 


\section{Seccurity}

implementation of the Law on Police and Law on Private Security also it does not mention the corporation as an entity that is subject to these regulations. In this case, these laws apply only institution to provide services to the Corporation. In this regard, the problem raises the issue of the functioning of the Law on Private Security Corporation of the institutions themselves. The state did not regulate the secondary legislation, and the same can not be applied. While the Corporation developed its own rules based on the laws that regulate the function of the Corporation.

\section{Defining corporate security}

Before we go on to possible definition and the definition of the concept of corporate or corporate security, it is necessary to point out to its original terms is characterized by, directed and characterized this name and its meaning. "Corporation, the specific legal form of organization of persons and material resources, which authorizes states in order to conduct a business. In contrast to two other important forms of business ownership, both individual and partnership, the corporation has several characteristics that make it more flexible instrument for large-scale economic aktrivnosti." If we consider the above definition as a basis for an explanation of our corporation, we reach a certain impression and conclusion. The corporation is an organized system and made a number of persons associated with its capital, which becomes the property of the persons called the Corporation, with the aim of doing business and the realization of capital. In this sense formed corporation, means the joint association of a group of people who have agreed, and joined together with their capital and become the owners of capital. What is important to note that the precise agreed percentage invested or attached kapitalalom. So affiliated persons or people in most cases are the same profession and the profession. This form of association based its roots in capitalist society, and stayed in the same system, and now in the majority, while i appeared in another form of organization that is in other systems on a smaller scale. To form a complete conceptual definition and the definition of a corporation with the appropriate bases and original words and their similarities, differences, ie, it is necessary to adopt other similar words such as: corporate, corporate system, corporatism etc. "Corporate latin not individually, but as an association (for. example, when appearances); total; in common. Thus, corporate, belongs to the capacity of a corporation that is related to a corporation, under which the company is made up of an association in which they are affiliated employers and workers, it is usually the same profession. "Corporation - is (latin korporation, v, korpus), Association, an organization of people of the same profession, 


\section{Secuurity}

occupation and the like. formed on the basis of group interests, guild, guild." In this regard the conceptual meaning of a corporation means an association of organized people and capital of the same profession and occupation with common interests, goals and acquiring capital, and thus profits. And finally, a word corporatism, also implies association, which is subordinated to the state and not the interests of a group of people, and in most cases this association formed in industrial production, and that the company would be determined by authority subordinate to the state or state authorities, and which would not controlled. In other words, corporatism would be considered corporate management of the corporation or an association owned by the state. Thus, the corporation is associated and organized activity interested groups and professional staff who have common goals and interests of the end for profit and capital. A time identified with the capitalist system that is not a country but an organized group. While, the association involves a corporate group of people of the same trade and profession, who manage the corporation and corporations that fit in front of the society.

\section{Models of corporate-integrated security Corporations in the Republic of}

\section{Serbia}

“Public-private partnership is a long-term contractual partnership between the public and private sectors, which may include the financing, design, construction, operation and/or maintenance of infrastructure and/or the provision of services by the private sector, which traditionally procured and provided by the public sector. When it comes to the implementation of public-private partnership, it is a model that brings benefit to both sides, which requires an effective combination of targets public and private sectors... Private security companies have become the reality of the implementation of security of many countries and are an integral part of their security sector. His presence fills the spaces that state institutions for objective and subjective reasons are not able to fill." The author is fully addressed in the discussion of the private sector within the framework of state institutions and the exercise of general security often quoted without specific companies, agencies or companies that provide security services. The majority of his work is devoted to private companies in public utilities, and military companies and their participation in the realization of security. When it comes to the relations between state and private partnership in the Republic of Serbia has a similar status but on a smaller scale and the capacity in which the private sector participates in the state sector. However, the private sector provides far less in terms of security within the state sector, its services are mostly offered and accepted in the private sector. Private security in 


\section{Seccurity}

the Republic of Serbia has also become a reality and occupies an important place in the realization of security, both in the private and state levels. For the purposes of this study were collected from a number of financial corporation Republic of Serbia, with the aim of reviewing their organization's security model. In this sense, it was identified and found similarities and differences corporate-corporate-conventional security guards. Model, organizing corporatecorporate security on the one hand, and agreed service security from the aspect of physical protection by conventional means and equipment safety.

\section{Models and experiences of security in corporations and companies}

\section{-Research results-}

1.3.1. The corporation state ownership Komercijalna Banka whose capital is associated with a $75 \%$ domestic and $25 \%$ foreign capital. However, security is organized on the model of the double security in one system. The security department of the Bank was organized by departments in the organization of the bank and contracted works with other professional institutions of private security. Thus, the Bank's internal security services are: informational, financial, business, data protection and security part of health at work. This type of organization includes corporate security. While the second part of the contracted security service activities with other institutions in the framework of the private sector for the protection and realization of safety and security services through: Physical and technical security, security of facilities, provision of money transportation, fire protection, security part of health, exercise fizičkko a conventional security because they use weapons, tools and equipment for these purposes. In addition to these service industries, performs and other forms of service delivery in the following: staff training, inspection and maintenance of protective equipment, contracts and risk assessment. When it comes to laws and statutory rules on the exercise of security apply to all laws of the Republic of Serbia relating to the security of that activity, while the bank's work safety (protection of classified information, information security, environmental security and economic security) which includes corporate security apply the Bank's standards, policies and legal documents on the functioning of the Bank. So, in this corporation is organized Corporate-agreed and conventional safety, according to the model of their own organization and consultation with other institutions of private security, which has given the Corporate condition-corporate and agreed security, which is surrounded by corporate security company. On the question whether the security of your 


\section{Secuurity}

corporate or corporate? To which an answer is corporate corporation itself, a security is its internal activity called corporation security. Thus in this corporation is organized as "Corporate security".

1.3.2. When it comes to SBERBANK in Belgrade, security service was organized by the two entities, i.e. from the bank's security and other institutions involved. When it comes to the bank's security organized by the professional services that perform safety through the Department of risks, the department of information security. Agencies involved from the composition of private security provide protection and realization of security through protection of buildings and persons, fire protection, technical protection and health and safety at work. Regarding the issue of the application of legal norms, mainly governed by the laws of the Republic of Serbia in the field of those services. When it comes to the application of foreign laws, which are related to safety recommendations apply to the country of origin of the Corporation. Therefore, in the above corporation organized corporate-agreed and conventional safety, which includes parts of the corporate and parts of other institutions and it, is doneintegrated corporate security.

1.3.3. Bank INTEZA, as the financial corporation with headquarters in Belgrade, prevails on the whole territory of the Republic of Serbia, with a specially organized security sector, which is defined with special security services through which covers the entire security of the Corporation. Internal corporate security is defined and organized through services for information security management service continuity of business services for the prevention and abuse, and services for the safety of health at work. When it comes to the safety engaged and agreed with other agencies is achieved through a team of physical security, technical security team, the field of protection and fire protection. Considering the organizational structure of the Corporation's security, also agreed a corporate and integrated safety and conventional protection, contained from corporate and other private security institutions. Also in this corporation shall be governed by the laws pertaining to the security of the Republic of Serbia, and the implementation of legal documents, the country of origin of corporations is done through procedures, recommendations and decisions.

1.3.4. OTP Bank with headquarters in Novi Sad is one of the few banks that security is organized and set the level of the Directorate for Security. The Directorate is organized into two departments i.e. Department of General Security Department and IT security. Department of General Safety deals with the protection and implementation of security through: Security technique, Security Bank, security against risk, the bank's security card, security facilities and safety of employees. Department of IT security is organized through specialized activities: Information technical (IT) security; is achieved through strategic planning, strategy encrypted 


\section{Seccurity}

protective operations, development gives software protection, security training, control functions and the like. As regards the application of legislation, apply to all legislation in the field of security of the Republic of Serbia. As far as the legal document banks apply all internal requirements such as security policy banks, Security Strategy, Rules of security OTP Bank, the bank's General Instructions, Guidelines for the Security of the risks, the Data Protection Ordinance, the Ordinance for protection against computer viruses, Rules for the IT system and the like. Consideration of the security system of the Corporation, has been organized by the system of free internal corporate security without special-involved other institutions.

- Exploring and trade institution METRO in Belgrade, where we have set up and their experience in achieving security retail chain of the company. Therefore, the realization of corporate security and data protection technology, information security, economic security and the like, is performed internal security companies, while physical technical and fire protection is via a conventional private security specialist for these purposes. These, and in this case it is a corporate-integrated safety from its own staff and engaged activities for securing people, property and facilities.

\section{Conclusion}

Conceived and incremental assumption of a dilemma and the name of corporate, private and conventional security are explored in corporations and companies that own and use this type of security. The study also indicated certain necessary information and that those names were stable in all forms in different corporations and companies. Planned research had for objective findings and confirmation that the real name of the corporate security or corporate or private way of security. The dilemma was solved based on identified responses to the questions, what is for them a corporate, what corporate and what is agreed upon private security. For questions received the answer that comes to corporate entities, corporate, private, integrated and conventional security. Based on these facts, the conclusion is that the Corporations are protected through corporate, private and integrated security using conventional equipment and resources. With the use of named subjects and their statements, we came to conclusion that is corporate security within corporation. So corporateintegrated and agreed security are ensured a unique name Corporate Security Corporation. Corporate name allowed us the basics of Corporate i.e. associated more people or entities with capital being created corporation. In addition, the above condition can also serve as a basis for 


\section{Seccurity}

the establishment of Security Corporation as independent institutions that will be part of a corporation with a market capital, and thus will provide a service to other corporations.

Planned and hypothesis as the assumption that the problem of the Law on safety in the Republic of Serbia, after the research has been partially confirmed and partially underwent. The hypothesis is not entirely confirmed as the legal norms in part carried out in the documents the corporation and the work of the Law of the Republic of Serbia. In security, fire protection and safety of health at work are organized under the Law of RS and implemented by the security services deployed outside the corporation. However, the internal security services (IT, economic and data protection) provide protection based on corporate policies and procedures. Therefore, in reality corporate security is organized as a Corporateconventional security, which protects the Corporation and its overall value.

\section{Literature}

1. Dragan Simeunović, Terorizam, Pravni fakultet, Beograd, 2009.

2. Ivan Klajin, Milan Šipka, Veliki rečnik stranih reči i izraza, Prometej, Novi Sad, 2006.

3. Milo Bošković, Zdravko Skakavac, Organizovani kriminalitet, Fakultet za pravne i poslovne studije, Novi Sad, 2009.

4. Milan Daničić, Ljubomir Stajić, Privatna bezbjednost, Visoka škola unutrašnjih poslova, Banja Luka, 2008.

5. Obren Đorđević, Leksikon bezbednosti, Partizanska knjiga, Beograd, 1986.

6. Robert Mikac, Suvremena sigurnost i privatne sigurnosne kompanije (privatizacija, sigurnost i poslijedice) Naklada Jesenski i Turk, Zagreb, 2013

7. Slobodan Marković, Korporativna i korporacijska bezbednost, Fakultet za pravne i poslovne studije dr Lazar Vrkatić, Novi Sad, 2014.

8. Grupa autora, Miodrag Simović i dr. Privatne bezbednosne komnpanije u Srbiji, prijatelji ili pretnje, Centra za civilno-vojne odnose, Beograd, 2008.

9. Grupa autra, Dragomir Jovičić i dr. Privatna bezbjednost u BiH i Republici Srpskoj, stanje i perspektive, Fakultet bezbjednosti i zaštite, Banja Luka, 2007.

10. Grupa autora, Zdravko Skakavac i dr. Privatna bezbednost, stanje i perspektive, Fakultet za pravne i poslovne studije, Novi Sad, 2008.

11. Grupa autora, Sonja Stojanović i dr. Primena savremenih metoda i sredstava u suzbijanju kriminaliteta, Internacionalna asocijacija kriminalista, Brčko, 2008. 


\section{Seccurity}

12. Pejanović Ljubo, Laković Vojo, Stojanović Stevan, Ugrožavanje i fizičko-tehnička zaštita, Institut za političke studije, Beograd, 2007.

13. Rakić Mile, Bezbednosna preventiva, Institut za političke studije, Beograd, 2006.

14. Simić R. Bošković M. Fizičko-tehnička zaštita objekata, Institut bezbednosti, Beograd, 1991. 